\title{
Eotaxin Triggers Eosinophil-Selective Chemotaxis and Calcium Flux via a Distinct Receptor and Induces Pulmonary Eosinophilia in the Presence of Interleukin 5 in Mice
}

\author{
Marc E. Rothenberg, ${ }^{* \dagger}$ Robert Ownbey, ${ }^{\ddagger}$ Paul D. Mehlhop, ${ }^{\S}$ \\ Paul M. Loiselle, " Matthijs van de Rijn," Joseph V. Bonventre," \\ Hans C. Oettgen, ${ }^{\S}$ Philip Leder,* and Andrew D. Luster \\ *Department of Genetics, Howard Hughes Medical Institute, Harvard \\ Medical School, Boston, Massachusetts, U.S.A. \\ †Department of Pediatrics, and \$Division of Immunology, Children's \\ Hospital, Boston, Massachusetts, U.S.A. \\ ${ }^{\ddagger}$ Infectious Disease Unit and "the Renal Unit, Department of \\ Medicine, Massachusetts General Hospital, Harvard Medical School, \\ Charlestown, Massachusetts, U.S.A. \\ "Department of Pathology and Laboratory Medicine, University of \\ Pennsylvania Medical System, Philadelphia, Pennsylvania, U.S.A.
}

\begin{abstract}
Background: Understanding the processes that control selective eosinophilia is of fundamental importance in a variety of human diseases (e.g., allergies, parasitic infections, malignancy). Interleukin 5, an eosinophil-specific growth and activating factor, and eotaxin appear to collaborate in this process. Eotaxin is a recently described chemotactic factor that belongs to the $\mathrm{C}-\mathrm{C}$ (or $\beta$ ) chemokine family and has been implicated in animal and human eosinophilic inflammatory states. We have recently reported the molecular characterization of murine eotaxin and now report the biological properties of purified recombinant murine eotaxin in vitro and in vivo in the presence or absence of interleukin 5 (IL-5) in mice.

Materials and Methods: Murine eotaxin was expressed in bacteria and purified by affinity chromatography and HPLC. Activity was tested in vitro by examining chemotactic and calcium flux responses of purified murine leukocytes. Additionally, desensitization of calcium flux responses to other chemokines, eosinophil survival assays, and basophil histamine release were examined. Finally, eotaxin was delivered to wild-type or IL-5 transgenic mice and the host response was examined.
\end{abstract}

Results: Eotaxin had activity only when the recombinant molecule had the native mature amino terminus and contained the first 25 amino acids of the mature protein. It was active in vitro at an effective concentration between 10 and $100 \mathrm{ng} / \mathrm{ml}$ in both chemotaxis and calcium flux assays toward eosinophils, but not macrophages or neutrophils. Furthermore, intranasal or subcutaneous application of eotaxin selectively recruited large numbers of eosinophils into the mouse lung and skin, respectively, only in the presence of interleukin 5 . Macrophage inflammatory protein-1 $\alpha$, a related C-C chemokine active on eosinophils, and eotaxin were not able to cross-desensitize. Eotaxin had no affect on the in vitro survival of eosinophils and did not induce basophil histamine release.

Conclusions: Mouse eotaxin is an eosinophil specific chemoattractant that has a markedly enhanced effect in vivo in the presence of another eosinophil selective cytokine IL-5, and utilizes a signal transduction receptor pathway that is distinct from that utilized by macrophage inflammatory protein-l $\alpha$. This data suggests that the development of tissue eosinophilia in vivo involves a two-step mechanism elicited by interleukin 5 and eotaxin.

Address correspondence and reprint requests to: Andrew D. Luster, Infectious Disease Unit, Massachusetts General Hospital, 149 13th Street, Charlestown MA 02129, U.S.A. email:luster@helix.mgh.harvard.edu,phone:

(617) 726-5710, fax (617) 726-5411 


\section{INTRODUCTION}

The occurrence of selective eosinophilia in a variety of human diseases (e.g., allergic disorders, parasitic infections, malignancy) suggests the importance of molecules specific to the regulation of eosinophil proliferation and tissue accumulation. Two molecules that appear to be involved in this process are interleukin 5 (IL-5) (1), an eosinophil selective growth and survival factor, and eotaxin, a recently described eosinophil active $\mathrm{C}$ - $\mathrm{C}$ chemokine (2-5).

The chemokines are a family of 8 - to $10-\mathrm{kD}$ chemoattractive cytokines which have been divided into three groups depending upon the primary sequence of the first two cysteines (6). The $\mathrm{C}-\mathrm{X}-\mathrm{C}$ and $\mathrm{C}-\mathrm{C}$ families are generally active on neutrophils and macrophages, respectively, and map to distinct chromosomal loci. Recently, a third family has been identified based on the presence of a single - $\mathrm{C}$ - and appears to be active toward lymphocytes (7). Chemokines induce chemotactic responses by binding to seven transmembrane-spanning $G$ protein-linked receptors that result in transient increases in intracellular calcium (8). The chemokines active toward eosinophils include the C-C chemokines: RANTES, macrophage inflammatory protein (MIP)- $1 \alpha$, monocyte chemoattractant protein (MCP)-2 and -3 , and eotaxin (9-11). Although five distinct $\mathrm{C}-\mathrm{C}$ chemokine receptors (CC CKR) have been identified (12-16) eosinophils appear to express only two of these (CC CKR-1 and -3) (Refs. 14, 15, and 17, and J.-L. Gao et al., submitted). RANTES and MIP- $1 \alpha$ cross-desensitize the calcium flux response in human eosinophils presumably via CC CKR-1 (10). However, it has been unclear which receptor is utilized by eotaxin.

Eotaxin was originally described as the chief eosinophil chemoattractive activity induced by allergen in a guinea pig model of allergic disease (2). We and others subsequently identified the guinea pig, mouse, and human eotaxin genes (2-5). High levels of eotaxin mRNA are detectable constitutively in multiple healthy tissues and may be responsible for promoting the baseline homing of eosinophils. Eotaxin mRNA is further increased during the early part of eosinophil recruitment in inflammatory models in animals and appears to be increased in the inflammatory lesions of patients with inflammatory bowel disease $(3,4,18-20)$. In addition, eotaxin mRNA rapidly accumulates in cytokine-activated epithelial and endothelial cells. Although eotaxin alone can induce eosinophil chemoattraction in vitro, it is likely that eotaxin works in concert with other cytokines produced during allergic and inflammatory responses. IL-5 is likely to be an important cytokine in these processes. The deletion of the IL-5 gene results in a profound deficiency in peripheral blood and allergen induced eosinophilia $(21,22)$. Conversely, the overproduction of IL-5 in transgenic mice (with a $\mathrm{T}$ cell promoter) results in massive eosinophilia (23). This eosinophilia is limited to the hematopoietic organs and the mice are generally healthy, suggesting that other tissue recruitment factors (e.g., chemokines) are necessary to produce tissue eosinophilia. In a recent report in guinea pigs, eotaxin was found to cooperate with IL-5 in inducing cutaneous eosinophilia (24). The biological properties of the purified mouse eotaxin protein have not been reported. In this report, we generate purified recombinant murine eotaxin and examine its cellular specificity at a wide range of doses, its ability to transduce calcium flux and cross-desensitize cellular signaling by other chemokines, and its effect in vivo in the absence and presence of the IL-5 transgene.

\section{MATERIALS AND METHODS}

\section{Recombinant Eotaxin Expression and Purification}

Recombinant murine eotaxin beginning with the putative mature amino terminal histidine ${ }^{24}$ and terminating with the carboxy-terminal proline ${ }^{97}$ was amplified by polymerase chain reaction (PCR) using the murine eotaxin cDNA as a template. The PCR primers were designed to amplify a sequence that contained BamHl sites on both ends and that would encode a protein with an amino-terminal factor Xa site (IEGR). Amplified cDNA was subsequently subcloned using a TA cloning kit (Invitrogen, San Diego, CA, U.S.A.) and confirmatory sequencing was performed. The eotaxin construct was liberated by BamHl digestion, cloned into the $B a m H l$ sites of Qiaexpress vector PQE8 (Qiagen Inc., Chatsworth, CA, U.S.A.), and then transformed into the Escherichia coli strain M15. Expression of eotaxin in pQE8 results in a fusion protein containing an amino-terminal Met-Arg-Gly-Ser-(His) 6 tag and the addition of Gly-Ser on the carboxy-terminal end (Fig. 1A, below).

Recombinant M15 E. coli containing the PQE8 plasmid engineered to express murine 
eotaxin were inoculated into Luria-Bertani medium supplemented with ampicillin $(100 \mathrm{mcg} /$ $\mathrm{ml})$ and kanamycin $(25 \mathrm{mcg} / \mathrm{ml})$ and grown with shaking at $37^{\circ} \mathrm{C}$ to an $\mathrm{OD}_{600}=0.7$. Isopropyl $\beta$-D-thiogalactopyranoside was then added to 2 $\mathrm{mM}$ final concentration to induce protein expression. Cultures were incubated for another 4 $\mathrm{hr}$ and then centrifuged at $4000 \times g$ for $20 \mathrm{~min}$ at $4^{\circ} \mathrm{C}$. The pellet was frozen at $-20^{\circ} \mathrm{C}$ overnight. After thawing for $15 \mathrm{~min}$ on ice, the bacterial pellet was resuspended in $6 \mathrm{M}$ guanidine $\mathrm{HCl}$, $0.1 \mathrm{M}$ sodium phosphate, and $0.01 \mathrm{M}$ Tris $\mathrm{HCl}$ (pH 8.0) at $5 \mathrm{ml} / \mathrm{g}$ wet bacteria. The suspension was sonicated on ice using a Branson model 450 sonifier with a microtip attachment at constant cycles and output of 4 for a total of $8 \mathrm{~min}$ (four 2 -min cycles). The sample was then centrifuged at $9500 \times g$ for $15 \mathrm{~min}$ at $4^{\circ} \mathrm{C}$ to remove cellular debris. The clarified supernatant was applied to a nickel-NTA (ProBond, Invitrogen) chromatography column that had been equilibrated by resuspension in the above $6 \mathrm{M}$ guanidine buffer. The column was washed with 10 column volumes of $6 \mathrm{M}$ guanidine buffer and four column volumes each of $8 \mathrm{M}$ urea, $0.1 \mathrm{M}$ sodium phosphate, and $0.01 \mathrm{M}$ Tris at $\mathrm{pH} 8.0,6.3$, and 5.9. Recombinant eotaxin was eluted from the column with the aforementioned $8 \mathrm{M}$ urea buffer, $\mathrm{pH} 8.0$, containing $0.25 \mathrm{M}$ imidazole. The protein was further purified by high-pressure liquid chromatography (HPLC) on a C4 reverse phase semipreparative column (\#214TP510, Vydac, Hesperia, CA, U.S.A.). Buffer A consisted of Milli Q $\mathrm{dH}_{2} \mathrm{O} / 0.1 \%$ trifluoroacetic acid (TFA) while buffer B was $95 \%$ acetonitrile $/ 0.1 \%$ TFA. The sample was loaded in $15 \%$ buffer B and run on a linear gradient on a Beckman System Gold HPLC apparatus (model 126). The gradient went from 15 to $35 \%$ buffer $B$ over $5 \mathrm{~min}$, then 35 to $50 \%$ over $15 \mathrm{~min}$, and eotaxin eluted at $\sim 40 \%$ buffer B. Fractions corresponding to peaks on the chromatogram were collected in separate tubes. These were then analyzed by SDS-PAGE to ascertain which peak represented murine eotaxin. Once this was established, the sample was frozen and lyophilized (Labconco Freezone model 4.5). The protein was resuspended in factor Xa buffer $(20 \mathrm{mM}$ Tris$\mathrm{HCl}, 100 \mathrm{mM} \mathrm{NaCl}, 2 \mathrm{mM} \mathrm{CaCl}, \mathrm{pH} \mathrm{8.0)}$ and digested overnight at room temperature with factor Xa (New England Biolabs, Beverly, MA, U.S.A.) at an enzyme/protein weight ratio of $1: 50$. The digested protein was purified by reverse phase HPLC using the conditions described above and then lyophilized and resuspended in $\mathrm{H}_{2} \mathrm{O}$. Protein concentration of the purified eotaxin protein was determined by comparing its $\mathrm{OD}_{550}$ to a dilution series of bovine serum albumen following the addition of the BCA reagent (Pierce, Rockford, IL, U.S.A.). Eotaxin at 0.5 $\mathrm{mg} / \mathrm{ml}$ was stable at $4^{\circ} \mathrm{C}$ for $>3$ months and contained $<5 \mathrm{ng} / \mathrm{ml}$ of endotoxin by use of the Limulus amebocyte lysate assay (Associates of Cape Cod, Woods Hole, MA, U.S.A.).

\section{Eotaxin in vivo Studies}

IL-5 transgenic mice (kindly provided by Dr. Colin Sanderson) (23) or wild-type (CBA/CaJ or 129SV) control mice were lightly anesthetized by inhalation of Metofane (Pittman-Moore, Mundelein, IL, U.S.A.) and $50 \mu \mathrm{l}$ of normal saline alone or containing recombinant eotaxin was applied to the left nare using a micro-pipettor with the mouse held in a supine position. After instillation, mice were held upright until alert.

Four hours after instillation, mice were euthanized by carbon dioxide inhalation, the thorax opened and the trachea exposed. A 24-gauge ball-tip needle on a l-cc syringe was introduced into the airway via a small incision on the ventral surface of the trachea. Phosphate-buffered saline $(0.8 \mathrm{ml})$ containing $10 \%$ fetal calf serum and 1 mM EDTA was infused then retrieved using the 1 -cc syringe, and the number of cells in the bronchoalveolar lavage (BAL) fluid was enumerated using a hemocytometer. A $100-\mu l$ aliquot of the fluid was applied to a glass slide by centrifugation at 400 RPM for $4 \mathrm{~min}$ in a Shandon Cytospin II centrifuge. The slides were air dried for $30 \mathrm{~min}$ before staining with Diff-Quik (Baxter Scientific Products, McGaw Park, IL, U.S.A.). The leukocyte differential was determined and the absolute eosinophil count derived as the product of the absolute leukocyte count and the eosinophil fraction on the leukocyte differential. After intratracheal BAL was performed, the lungs were fixed in $10 \%$ neutral buffered formalin under mild vacuum. Tissues were embedded in paraffin and $5-\mu \mathrm{m}$ sections were cut and stained by hematoxylin and eosin.

In other experiments, IL-5 transgenic or wild-type mice (CBA/CaJ) were subcutaneously injected with $100 \mu \mathrm{l}$ of phosphate-buffered saline alone or containing $0.1-1000$ pmoles of eotaxin. After 1, 3, 6, 24, 48, and $72 \mathrm{hr}$, the mice were euthanized by carbon dioxide inhalation and the tissue surrounding the injection site was removed and fixed in neutral buffered formalin. Tissue sections $(10 \mu \mathrm{m})$ were cut and stained with hematoxylin and eosin or giemsa. 


\section{Chemotaxis Assays}

Murine eosinophils were isolated from IL-5 transgenic mice (23). These mice develop splenomegaly, with eosinophils accounting for $\sim 30 \%$ of the splenocytes. Eosinophils were purified from the spleen using immuno-magnetic separation to remove the contaminating splenocytes. Splenocytes were subjected to hypotonic lysis to remove erythrocytes and the remaining leukocytes were labeled with anti-Thy-1 (M5/49), anti-B220 (6B2), and anti-Lyt-2 (53-6.7). Hybridoma cell lines were obtained from American Type Culture Collection and hybridoma cell supernatants were used as a source of antibodies. The antibody labeled cells were treated with sheep anti-rat serum-coated magnetic beads (M450; Dynal, Great Neck, NY, U.S.A.) and eosinophils were enriched by negative selection through a magnetic field. The resulting eosinophil preparations were $>92 \%$ pure. Macrophages cells were isolated from the peritoneal cavity of mice that had been pretreated ( 2 days prior) with intraperitoneal injection of $1 \mathrm{ml}$ of $2.9 \%$ thioglycollate (Difco, Detroit, CA, U.S.A.) (25). Neutrophils were isolated from the peritoneal cavity of mice that had been pretreated with intraperitoneal injection of $9 \%$ sodium casein (Sigma Chemical Co., St. Louis, MO, U.S.A.) 18 and $4 \mathrm{hr}$ prior to isolation (25). Macrophages and neutrophils were further purified by centrifugation in self-forming Percoll gradients and were $>90 \%$ pure. Eosinophils, macrophages, and neutrophils were suspended in HBSS with $0.05 \%$ BSA at 2,5 , and $1 \times 10^{6}$ cells $/ \mathrm{ml}$, respectively, and replicate cells were placed in the top well of a 48-well micro-chemotaxis chamber (Neuro Probe, Inc., Cabin John, MD, U.S.A.). A polycarbonate filter with $5-\mu \mathrm{m}$ pores (eosinophils and macrophages) and a PVP-free filter with $3-\mu \mathrm{m}$ pores (neutrophils) separated the cells from buffer alone or buffer containing recombinant murine eotaxin, murine MIP- $1 \alpha$, murine MIP-1 $\beta$, murine MCP-1, (R\&D Systems, Minneapolis, MN, U.S.A.), human IL-8 (Genzyme, Cambridge, MA, U.S.A.), FMLP (Sigma), and PAF (Calbiochem, La Jolla, CA, U.S.A.). Cells were incubated at $37^{\circ} \mathrm{C}$ for $30 \mathrm{~min}$ (neutrophils), $60 \mathrm{~min}$ (eosinophils), or $90 \mathrm{~min}$ (macrophages), and the cells that migrated across the filter and adhered to the bottom side of the filter were stained with Diff-Quick. The number of cells per $400 \times$ field were counted.

\section{Calcium Flux Assays}

Cells $\left(2 \times 10^{6} / \mathrm{ml}\right)$ were incubated with Dulbecco's modified Eagle's medium (DMEM) medium with $1 \%$ heat-inactivated bovine calf serum containing the acetoxymethyl ester of fura-2 (Molecular Probes, Eugene, OR, U.S.A.) at $5.0 \mu \mathrm{M}$ for $60 \mathrm{~min}$ at $37^{\circ} \mathrm{C}$ in the dark. Cells were washed twice with flux buffer $(145 \mathrm{mM} \mathrm{NaCl}, 4 \mathrm{mM} \mathrm{KCl}$, $1 \mathrm{mM}$ sodium phosphate monobasic, $0.8 \mathrm{mM}$ $\mathrm{MgCl}_{2}, 1.8 \mathrm{mM} \mathrm{CaCl}{ }_{2}, 25 \mathrm{mM}$ HEPES, and 22 $\mathrm{mM}$ glucose) and resuspended at $2 \times 10^{6}$ cells/ $\mathrm{ml}$. Two milliliters of cells were placed in a continuously stirring cuvette at $37^{\circ} \mathrm{C}$ in a dual-wavelength excitation source (Photon Technology, Inc., South Brunswick, NJ, U.S.A.). Fluorescence was monitored at excitation frequencies of 340 and $380 \mathrm{~nm}$, and emission was recorded at $510 \mathrm{~nm}$. The data is presented as the relative ratio (R) of fluorescence at 340 and $380 \mathrm{~nm}$. A maximum and minimum signal was obtained by the addition of Triton X-100 and ethyleneglycol-bis-N,N-tetraacetic acid (EGTA), respectively. The intracellular calcium concentration was measured according to the formula [Ca $]_{\mathrm{i}}=224 \mathrm{nM} \times[(\mathrm{R}-\mathrm{Rmin}) /(\mathrm{Rmax}-$ R)], assuming a $K_{\mathrm{d}}$ of $224 \mathrm{nM}(26)$.

\section{Eosinophil Survival Assays}

Survival was calculated as previously described (27). Briefly, murine eosinophils were purified as described above and resuspended in RPMI-1640 medium supplemented with $10 \%$ fetal bovine serum, and $1 \times 10^{5}$ cells were placed the wells of a 96-well plate in $200 \mu \mathrm{l}$ of medium alone or medium containing $5 \mathrm{pM}$ recombinant murine IL-5 (Genzyme) or medium containing murine eotaxin at various concentrations. After 3 days, an equal volume of Trypan blue was added to the wells and the number of cells excluding the Trypan blue were calculated.

\section{Basophil Histamine Release Assays}

Histamine release was determined by modifying the previously reported methods (28-30). The peripheral blood of two human donors (one healthy and one mildly-atopic) was subjected to centrifugation over Ficoll-Paque (Pharmacia, Piscataway, NJ, U.S.A.), and the top layer of cells was resuspended at $3 \times 10^{6}$ cells $/ \mathrm{ml}$ in buffer containing $125 \mathrm{mM} \mathrm{NaCl}, 5 \mathrm{mM} \mathrm{KCl}, 1 \mathrm{mM}$ $\mathrm{MgCl}_{2}, 1 \mathrm{mM} \mathrm{CaCl} 2,0.5 \mathrm{mM}$ glucose, and $0.025 \%$ BSA. Aliquots of the cells were warmed to $37^{\circ} \mathrm{C}$, exposed to buffer alone or containing 
human IL-3 (Genzyme) or human IL-5 (Genzyme) at $10 \mathrm{ng} / \mathrm{ml}$ for $10 \mathrm{~min}$, and then challenged with recombinant murine eotaxin, human eotaxin, MCP-1, or MCP-3 (Pepro-Tech Inc., Rocky Hill, NJ, U.S.A.). After 20 min, the cells were centrifuged and the supernatant was analyzed for the histamine content by use of an enzyme immunoassay (Immunotech, Westbrook, ME, U.S.A.). Histamine release was expressed as the percentage of the total content of the sample (determined after cell lysis with a sonicator).

\section{RESULTS}

\section{Preparation of Recombinant Eotaxin}

Eotaxin was produced in bacteria by attaching a tag containing six histidines to the amino-terminal end of eotaxin. This strategy was used since the histidine tag has a strong avidity to nickel even in the presence of strong chaotropic agents such as guanidine hydrochloride. The material that eluted from a nickel agarose column was subsequently subjected to reverse phase HPLC to further purify the protein. In preliminary experiments with guinea pig eotaxin, it was determined that eotaxin produced in such a manner had minimal chemotactic activity in vitro (data not shown). Because the presence of an unmodified amino-terminal amino acid has been shown to be critical for the biological activity of MCP-1 $(31,32)$, a chemokine very homologous to eotaxin, the murine eotaxin expression construct was designed to place a factor Xa consensus site between the histidine tag and eotaxin (Fig. 1A). Purified eotaxin (with the tag) had an apparent Mr of $\sim 12.5 \mathrm{kD}$ when electrophoresed in a denaturating polyacrylamide gel and was found to contain higher molecular weight species most likely from protein aggregation (Fig. 1B). The larger apparent $M_{r}$ of the recombinant eotaxin protein (predicted $M_{\mathrm{r}}: \sim 10,438 \mathrm{kD}$ ) is likely due to the presence of the basic histidine tag (33). The purified histidine-tagged eotaxin protein was subjected to Xa digestion. SDS-PAGE analysis of the factor Xa digested (his) ${ }_{6}$-tagged eotaxin revealed two digestion products $(\sim 6$ and $\sim 9 \mathrm{kD})$ which were subsequently purified by reverse phase HPLC and subjected to N-terminal sequencing. Sequence analysis revealed that the protein preparation containing the larger band (Lane 5 in Fig. 1B) was appropriately cleaved, generating eotaxin with the native $\mathrm{N}$ terminus (HPGSIPTS). The smaller band (Lane 3 in

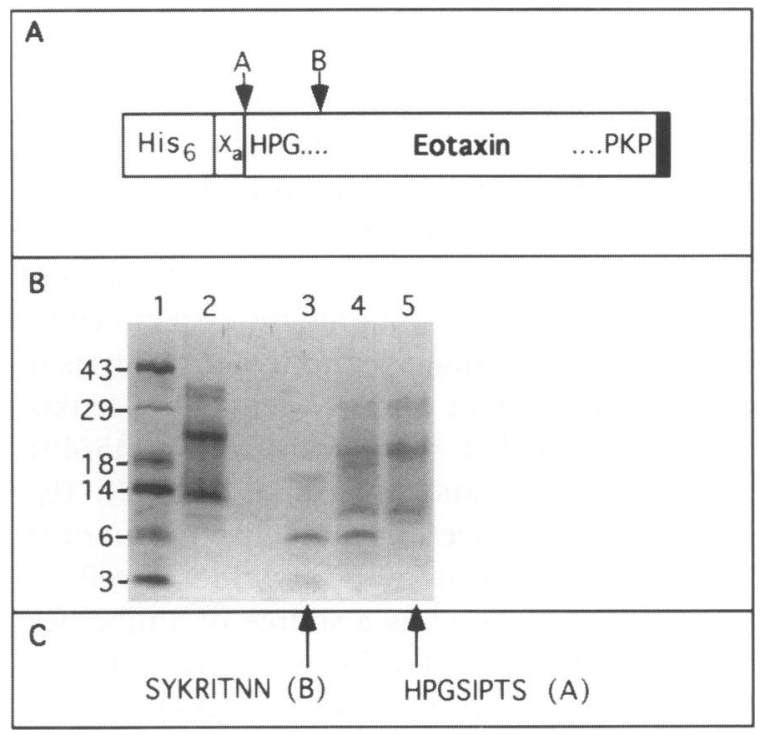

FIG. 1. Production of recombinant murine eotaxin

(A) Eotaxin was engineered for expression in bacteria by placing an amino-terminal tag containing six histidines (box with $\mathrm{His}_{6}$ ) and a factor Xa consensus sequence (box with $X_{a}$ ) from the mature sequence. The carboxy-terminal sequence contained two additional amino acids (black box). Factor Xa digestion resulted in cleavage of the tagged-construct at two sites (designated $\mathrm{A}$ and $\mathrm{B}$ with the arrows). (B) Comassie stained $12.5 \%$ SDS-PAGE (Tris/Tricine) of eotaxin protein. Low-molecular weight standards (Lane 1) and their values in $\mathrm{kD}$ are indicated to the left. Eotaxin was purified by Nickel and reverse phase HPLC chromatography (Lane 2) and subsequently subjected to Xa digestion. Subsequent HPLC analysis resulted in the separation of two different cleavage products, designated A (Lane 5) and в (lane 3 ), and a mixture of the two (Lane 4). (C) N-terminal amino acid sequence analysis for the samples in Lanes 3 and 5 is indicated.

Fig. 1B) was incorrectly digested resulting in an $\mathrm{N}$-terminal deletion of 25 amino acids in eotaxin (starting at SYKRITNN). It is noteworthy to mention that the protein preparations used for $\mathrm{N}$ terminal sequencing contained the mixture of the higher molecular bands shown in Fig. 1B; however, the sequencing revealed only one molecular species. This provided support that the higher molecular weight bands were indeed aggregates of the monomer.

\section{Eotaxin Induced Chemotaxis}

The native histidine-tagged eotaxin protein and the Xa-digested eotaxin products following HPLC 


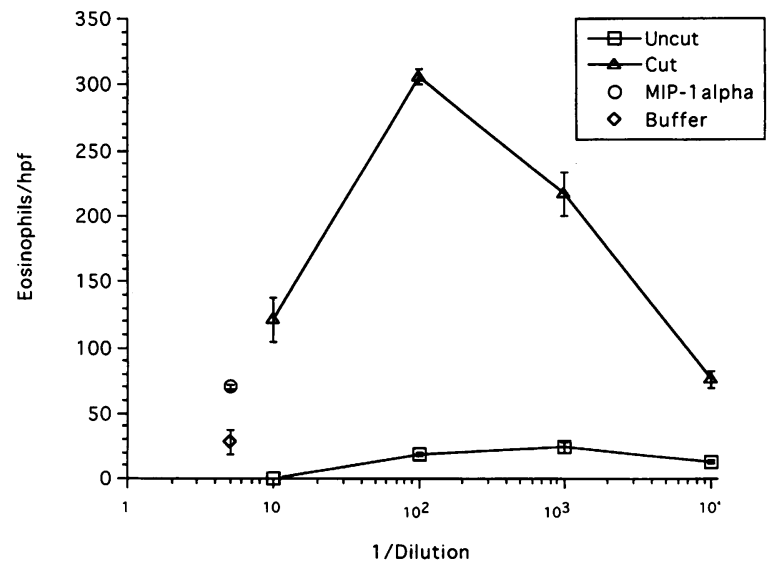

FIG. 2. Chemotaxis of murine eosinophils to recombinant eotaxin before or after Xa cleavage

(His) ${ }_{6}$-eotaxin purified from E. coli by Nickel and reverse phase HPLC chromatography was resuspended in water at $\sim 30 \mu \mathrm{g} / \mathrm{ml}$. The chemotactic response of this protein was then tested before (Uncut) and after factor Xa digestion (Cut) without further purification. The chemotactic response to $100 \mathrm{ng} / \mathrm{ml}$ of MIP- $1 \alpha$ and buffer alone are also indicated. The results are expressed as the mean \pm SEM for replicate samples.

purification were tested in an eosinophil chemotaxis assay in vitro. Only Xa cleaved eotaxin had chemotactic activity (Fig. 2). When each protein was tested for their biological activity on eosinophils, the purified eotaxin liberated at the internal cleavage site (B) had no activity, whereas the protein generated with the native amino terminus (A) had activity (data not shown). Additionally, the fraction that contained both bands had full biological activity, indicating that product $B$ did not have significant inhibitory activity. These results demonstrate that eotaxin generated in bacteria is biologically active only when there is a native mature amino terminus.

Eosinophils were exposed to purified eotaxin at doses ranging from 0 to $1000 \mathrm{ng} / \mathrm{ml}$ and $\mathrm{ex}$ hibited a dose-dependent increase in their chemotactic response (Fig. 3A) between 5 and 50 $\mathrm{ng} / \mathrm{ml}$. Macrophages were similarly tested and exhibited no chemotactic response to eotaxin at any dose tested (Fig. 3B). As positive controls (6), replicate macrophages responded to murine MIP- $1 \alpha$ and FMLP (Fig. 3B). Additionally, neutrophils exhibited no response to eotaxin whereas they had a strong response to control agents (6), human IL-8 and FMLP (Fig 3C). These results demonstrate that purified eotaxin, at a wide range of doses, is a direct and selective chemotactic cytokine for eosinophils in vitro.

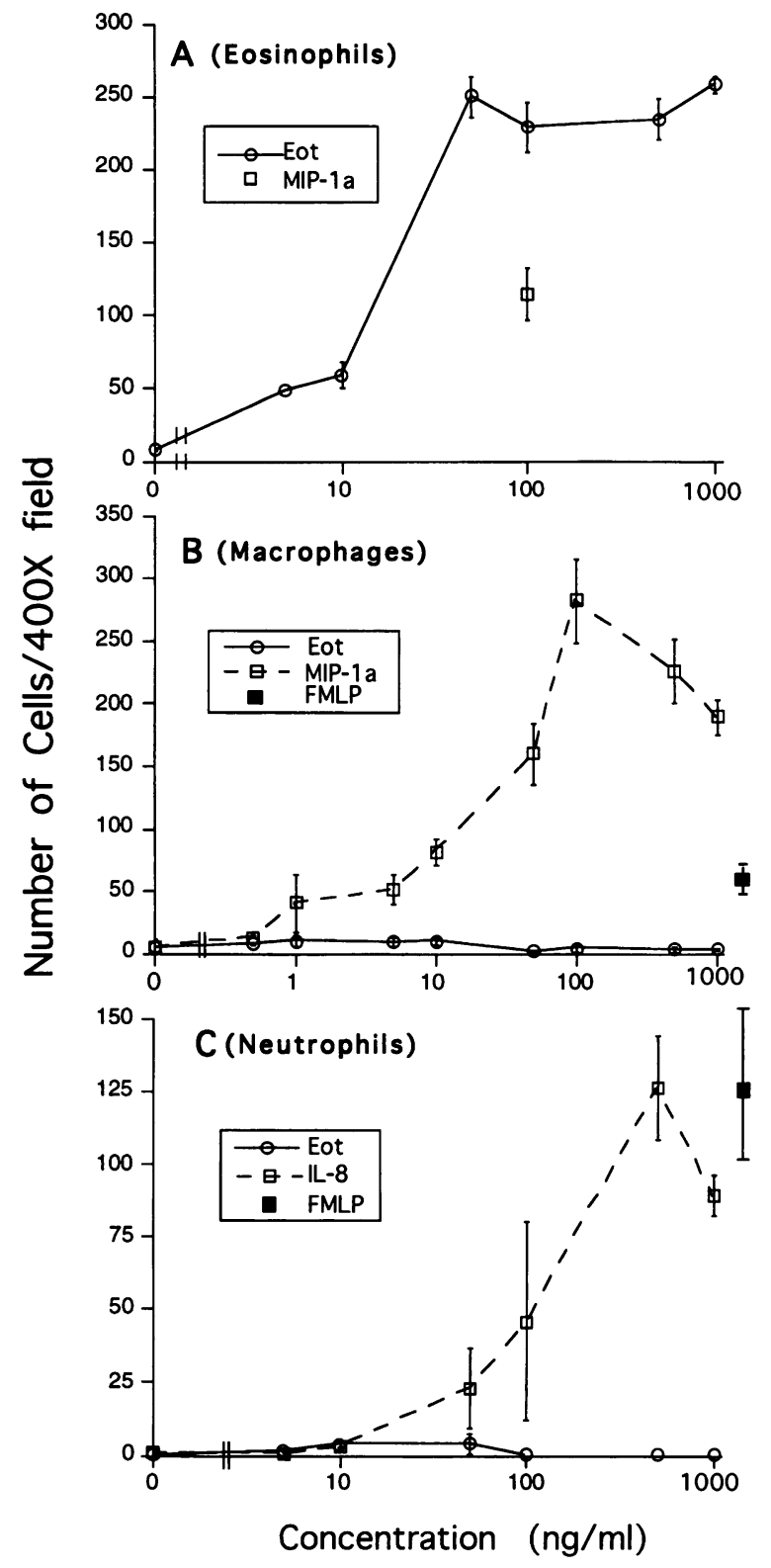

FIG. 3. Chemotaxis of murine leukocytes to different concentrations of eotaxin

Eosinophils (A), macrophages (B), and neutrophils (C) were subjected to chemotaxis in a modified Boyden chamber and the number of cells that migrated through the membrane were counted. Control chemotactic stimuli are indicated. The results are expressed as the mean \pm SEM for replicate samples.

\section{Eotaxin Induced Calcium Flux in Eosinophils}

Chemoattractive responses induced by other chemokines are associated with a transient rise in intracellular calcium following receptor bind- 


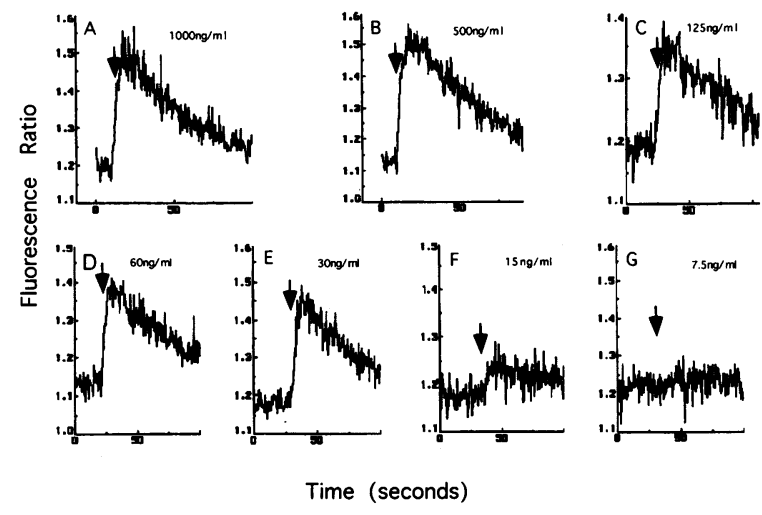

FIG. 4. Calcium flux in eosinophils in response to various concentrations of eotaxin

Eosinophils were loaded with the calcium sensitive dye, fura-2, and their response to different concentrations of eotaxin (indicated with arrows) was assessed in a fluorimeter. The data is expressed as the ratio of emission at $510 \mathrm{~nm}$ after excitation at 340 and $380 \mathrm{~nm}$, respectively.

ing. We therefore tested the ability of eotaxin to induce a calcium flux in eosinophils. Eosinophils were loaded with the calcium-sensitive fluorescent dye, fura-2, and their response to eotaxin was monitored in a fluorimeter. Eotaxin induced a transient rise in intracellular calcium in a dosedependent manner (Fig. 4). The threshold for observing an effect was $\sim 15 \mathrm{ng} / \mathrm{ml}$ and a maximum effect was seen at $\sim 100 \mathrm{ng} / \mathrm{ml}$ with a plateau at higher concentrations. Intracellular calcium concentrations were calculated to be $\sim 75$ $\mathrm{nM}$ in resting eosinophils and $220 \mathrm{nM}$ in eosinophils stimulated with eotaxin $(1000 \mathrm{ng} / \mathrm{ml})$.

\section{Calcium Flux in Macrophages and Neutrophils}

The cellular specificity of eotaxin was further examined utilizing calcium flux as an assay. Macrophages had no calcium flux triggered in response to a wide range of doses of eotaxin, including $1000 \mathrm{ng} / \mathrm{ml}$, while the same macrophages had a brisk response to murine MIP- $1 \alpha$, murine MIP-1 $\beta$, and a lesser response to FMLP (Fig. 5). Similarly, the response of neutrophils to eotaxin was examined. Neutrophils exhibited a small response to human IL-8 and larger responses to murine MIP- $1 \alpha$, murine MIP- $1 \beta$, and FMLP, but had no response to a full range of doses of eotaxin (Fig. 6). These results demon-

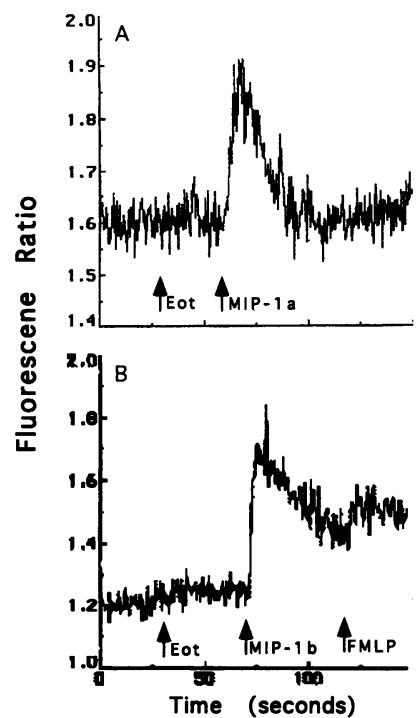

FIG. 5. Calcium flux in macrophages in response to various stimuli

(A) Macrophages were exposed to eotaxin (1000 ng/ $\mathrm{ml}$ ) and then MIP- $1 \alpha(200 \mathrm{ng} / \mathrm{ml})$. (B) Macrophages were exposed to eotaxin $(1000 \mathrm{ng} / \mathrm{ml})$ and then MIP- $1 \beta(200 \mathrm{ng} / \mathrm{ml})$ and FMLP $\left(10^{-7} \mathrm{M}\right)$.

strate that eotaxin is selective for eosinophils utilizing calcium flux as a biological response.

\section{Desensitization Studies}

Rapid successive exposure to the same ligand is known to desensitize the signaling capacity of $G$ protein-linked receptors. Likewise, exposure of cells to different ligands that utilize the same receptor can also result in desensitization (34). We were therefore interested in determining if other chemotactic cytokines were able to also induce a calcium flux in murine eosinophils and if these cytokines and eotaxin were able to crossdesensitize to each other. The first cytokine response that was examined was the ability of eotaxin to desensitize to itself. At high doses of eotaxin $(1000 \mathrm{ng} / \mathrm{ml})$, eotaxin completely desensitized a subsequent cellular response to eotaxin challenge (Fig. 7A). However, the same cells were not desensitized to respond to murine MIP- $1 \alpha$ (Fig. 7A). Conversely, murine MIP- $1 \alpha$ induced a modest calcium flux in eosinophils (Fig. 7B). This resulted in self-desensitization, but did not affect subsequent cellular signaling by eotaxin (Fig. 7B). The ability of eotaxin to desensitize to itself was dose dependent and was not seen at a lower dose of eotaxin (30 ng/ml) (Fig. 7C). Additionally, 


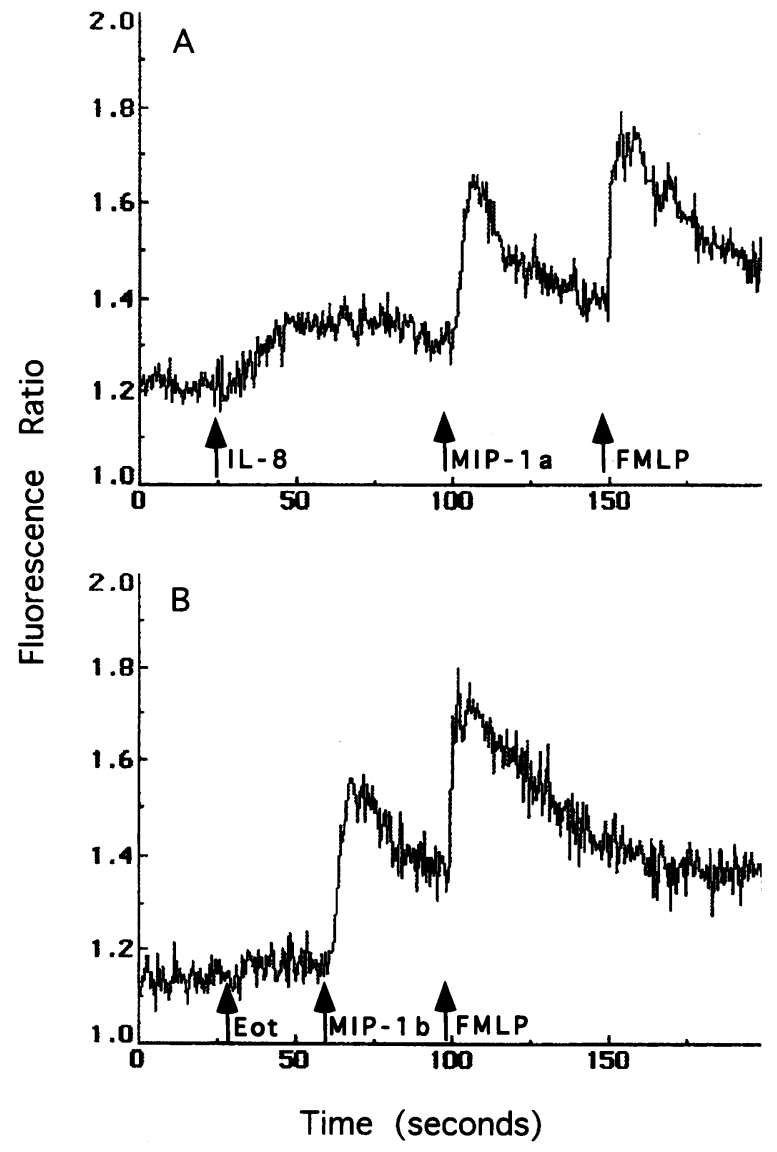

FIG. 6. Calcium flux in neutrophils in response to various chemokines

(A) Neutrophils were exposed to IL-8 $(200 \mathrm{ng} / \mathrm{ml})$, MIP-l $\alpha(200 \mathrm{ng} / \mathrm{ml})$, and FMLP $\left(10^{-7} \mathrm{M}\right)$. (B) Neutrophils were exposed to eotaxin $(1000 \mathrm{ng} / \mathrm{ml})$ MIP-1 $\beta(200 \mathrm{ng} / \mathrm{ml})$, and FMLP $\left(10^{-7} \mathrm{M}\right)$.

murine MCP-1 and murine MIP-1 $\beta$ (Fig. 7D) did not induce calcium flux in eosinophils and did not affect subsequent eotaxin-induced signaling. Eotaxin treatment did not affect subsequent calcium flux by PAF (data not shown). Furthermore, human RANTES did not induce calcium flux in murine eosinophils (data not shown) consistent with its lack of chemotactic activity for murine eosinophils (15). Human MCP-2 and -3 , human $\mathrm{IL}-8$, and murine $\mathrm{KC}$ also had no effect on murine eosinophils (data not shown).

\section{Eotaxin Induced Eosinophilia in Vivo}

Since it was possible that eotaxin might recruit other cell types in addition to eosinophils, it was of interest to determine the specificity of eotaxin in vivo. It was also of interest to determine if
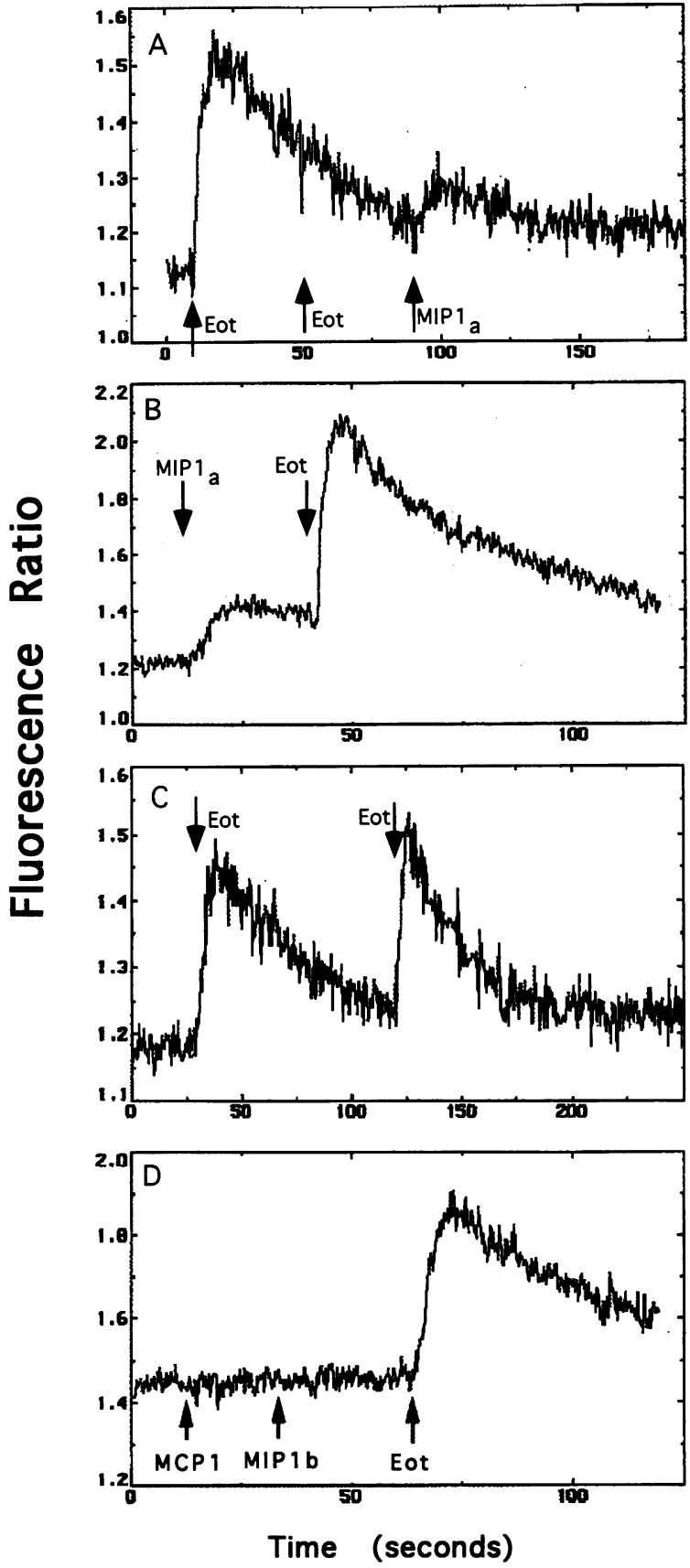

FIG. 7. Calcium flux in eosinophils in response to various chemokines

(A) Eosinophils were exposed to eotaxin (1000 ng/ $\mathrm{ml}$ ) and subsequently to another dose of eotaxin $(1000 \mathrm{ng} / \mathrm{ml})$ followed by MIP- $1 \alpha$ exposure $(200$ $\mathrm{ng} / \mathrm{ml}$ ). (B) Eosinophils were exposed to MIP- $1 \alpha$ $(1000 \mathrm{ng} / \mathrm{ml})$ and then to eotaxin $(250 \mathrm{ng} / \mathrm{ml})$. (C) Eosinophils were exposed to a lower concentration $(30 \mathrm{ng} / \mathrm{ml})$ and then to a higher concentration (1000 $\mathrm{ng} / \mathrm{ml}$ ) of eotaxin. (D) Cells were exposed to MCP-1 $(200 \mathrm{ng} / \mathrm{ml}), M I P-1 \beta(200 \mathrm{ng} / \mathrm{ml})$, and then to eotaxin $(1000 \mathrm{ng} / \mathrm{ml})$. 


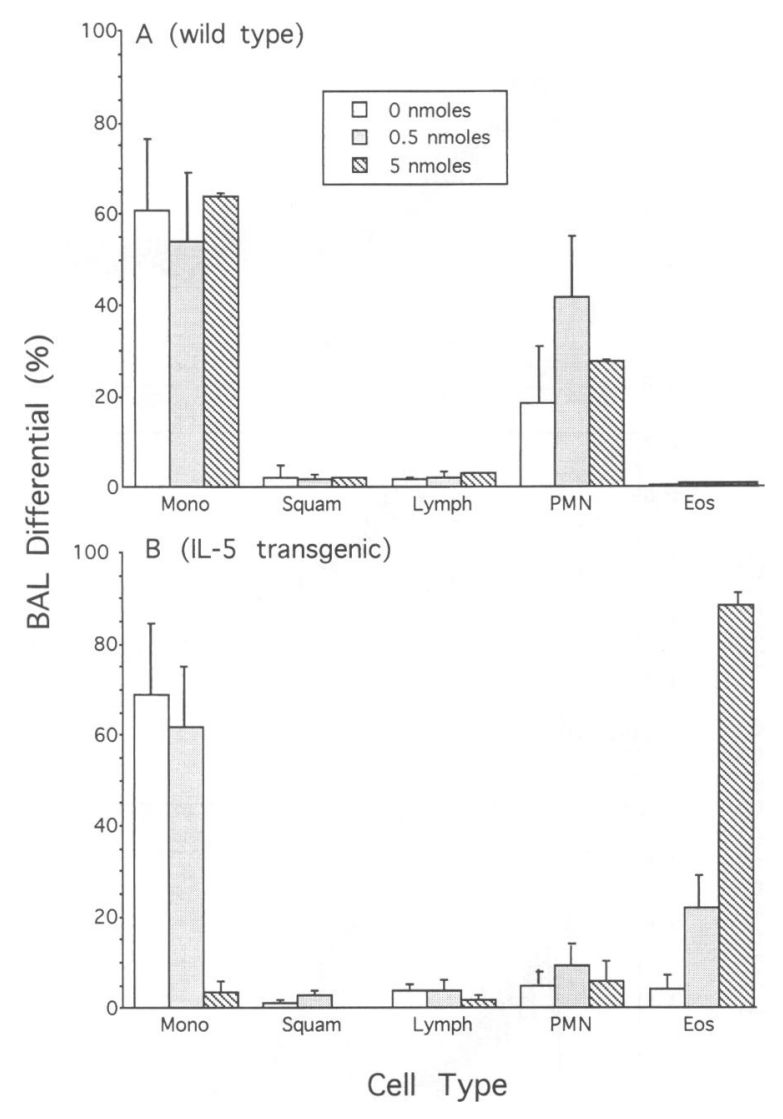

FIG. 8. Intranasal application of eotaxin to mice and resultant BAL cellular composition Eotaxin was delivered to wild-type (A) or IL-5 transgenic mice (B) at 0 (normal saline), 0.5 , or 5.0 pmoles and the cellular composition in the BAL fluid was assessed after $4 \mathrm{hr}$. Results are expressed as the mean $\pm \operatorname{SEM}(n=3)$.

eotaxin alone was sufficient to induce eosinophil recruitment in vivo. The delivery of cytokines and antigens by intranasal instillation has been shown to elicit a pulmonary inflammatory response $(35,36)$. Eotaxin was therefore delivered to anesthetized mice by intranasal application of 0.5 and 5.0 nmoles or normal saline alone. Four hours after treatment, the mice were sacrificed and the cellular count and composition in the BAL was analyzed. In wild-type mice, there was no consistent difference in the total number of BAL cells (data not shown) or the cellular composition (Fig. 8A). In two of six eotaxin-treated mice, there was a detectable increase in the number of BAL eosinophils (Fig. 9).

IL-5 transgenic mice have large numbers of eosinophils in the hematopoietic organs and blood but few in the tissue such as the lungs.

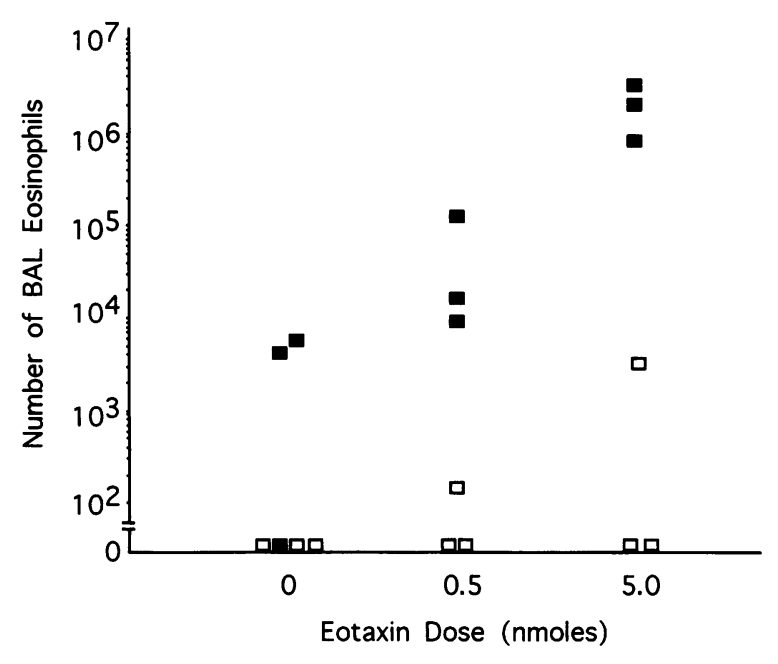

FIG. 9. Induction of pulmonary eosinophilia following eotaxin treatment

The number of BAL eosinophils was determined 4 hr after treatment with intranasal eotaxin. Each data point represents one animal. Open squares are wildtype mice and closed squares are IL-5 transgenic mice.

These eosinophils are likely to be primed to respond to eotaxin since IL- 5 has been shown to prime human eosinophils to respond to other stimuli (27) including chemoattractants such as RANTES, PAF, and FMLP $(37,38)$. Consequently, it was of interest to determine if the application of eotaxin to IL-5 transgenic mice would elicit pulmonary eosinophilia. When eotaxin was delivered to these mice, there was a marked increase in the total number of BAL cells which was entirely due to an increase in the number of eosinophils. Normal saline-treated IL-5 transgenic mice had a mean of $4.3 \%$ eosinophils and this level rose to a mean of 22 and $88 \%$ following 0.5 and 5.0 nmoles of intranasal eotaxin, respectively (Fig. 8B). No other cell type was recruited into the BAL fluid (Fig. 8B). When the total eosinophil count was determined in the BAL following eotaxin treatment, there was a large increase in the number of eosinophils. The normal saline-treated mice had a mean of $3.2 \times 10^{3}$ eosinophils and the eotaxin-treated mice had a mean of $5.0 \times 10^{4}$ and $2 \times 10^{6}$ eosinophils after 0.5 and 5.0 nmoles of eotaxin, respectively (Fig. 9). No increase was seen in other cell types.

Representative photomicrographs of BAL cells recovered following normal saline treatment (Fig. 10A) or eotaxin treatment (Fig. 10B) of IL-5 transgenic mice are shown. Pathological 

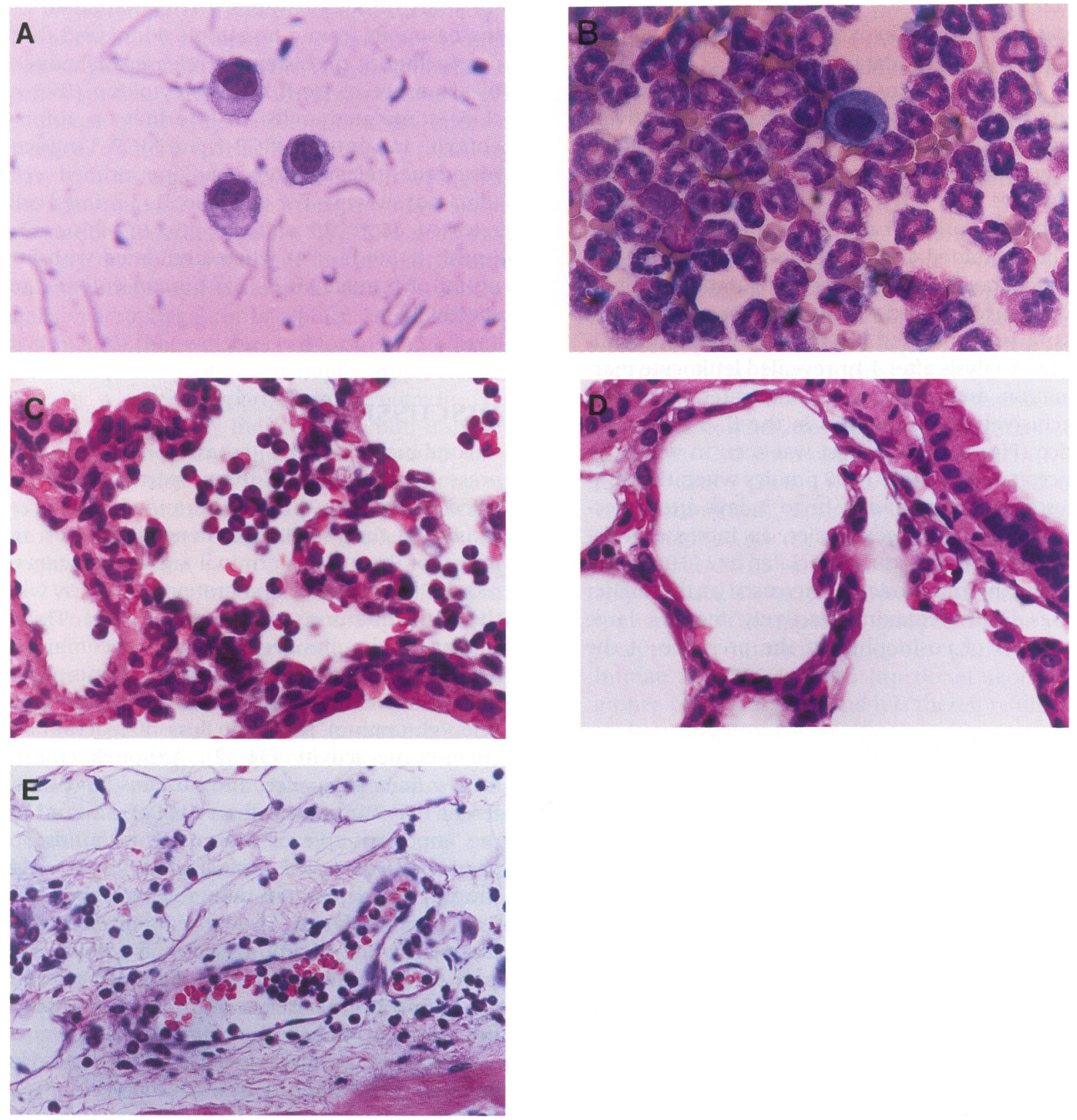

FIG. 10. Photomicrograph of BAL cells and tissue sections after eotaxin treatment

IL-5 transgenic mice were exposed to intranasal normal saline (A) or 5.0 nmoles of eotaxin (B) and the BAL cells were cytocentrifuged and stained with Diff-Quick. Tissue sections from the lungs of IL-5 transgenic mice $4 \mathrm{hr}$ after treatment with 5.0 nmoles of eotaxin (C) or normal saline (D). A section of the subcutaneous tissue of IL-5 transgenic mice $1 \mathrm{hr}$ after subcutaneous injection of 10 pmoles of eotaxin is shown in Panel E. Photomicrographs were taken at $400 \times(\mathrm{A}, \mathrm{B}$, and $\mathrm{E})$ and $600 \times(\mathrm{C}$ and $\mathrm{D})$.

sections from the lungs of mice were also examined. IL-5 transgenic mice treated with eotaxin showed a dense eosinophilic infiltrate. The majority of the eosinophils were present in alveolar capillaries with marked egress into the alveolar airspace (Fig. 10C). In addition, increased num- bers of eosinophils were noted in the peribronchiolar connective tissue and within small vessels in the interstitium. In contrast, IL-5 transgenic mice treated with normal saline showed only scattered pulmonary eosinophils, located predominantly within alveolar capillaries (Fig. 10D). 
Additionally, strain matched wild-type mice treated with eotaxin exhibited no significant pulmonary changes (data not shown).

The dose of intranasal eotaxin required to induce pulmonary eosinophilia was relatively high compared with that required to induce cutaneous eosinophilia in guinea pigs $(2,24)$. It was therefore of interest to administer murine eotaxin via another route that allowed its affects to be examined directly at the site of administration. Eotaxin was injected subcutaneously into IL-5 transgenic and wild-type mice, and the local tissue was analyzed for the inflammatory infiltrate. Analysis after $1 \mathrm{hr}$ revealed leukocyte margination and perivascular infiltrates composed exclusively of eosinophils in the IL-5 transgenic mice (Fig. 10E). No effect was seen in wild-type mice at doses of 0.1-1000 pmoles when the samples were analyzed at $1 \mathrm{hr}$ to 3 days after injection. In IL-5 transgenic mice, an increase in tissue eosinophilia was appreciated at 1-10 pmoles of eotaxin and modestly increased at the higher doses. Thus, eotaxin selectively induces large numbers of eosinophils in the presence of the IL-5.

\section{Eosinophil Survival}

Eosinophil tissue survival is thought to depend upon inhibition of apoptosis by eosinophil directed survival factors such as IL-5 $(27,39)$. In the mouse system, the ability of IL- 5 to maintain eosinophil survival has not been tested. It was also of interest to determine if eotaxin was able to maintain eosinophil survival. Murine eosinophils $(n=2)$ from IL-5 transgenic mice were found to depend upon IL-5 for their survival in vitro. Whereas only $3.1 \pm 2.1 \%$ (mean \pm SD) of the eosinophils survived in medium alone, $83 \pm$ $5 \%$ survived in the presence of 5 pM IL-5. In contrast, eotaxin did not enhance the survival of replicate eosinophils since only $1 \pm 0.2,1.5 \pm$ $0.6,5.6 \pm 2.5,2.9 \pm 0.3$, and $2.2 \pm 0.4 \%$ of the eosinophils survived at 50, 100, 250, 500, and $1000 \mathrm{ng} / \mathrm{ml}$ of eotaxin.

\section{Human Basophil Histamine Release}

Chemokines related to eotaxin (e.g., MCP-1 and -3, MIP- $1 \alpha$ ) have been shown to stimulate the release of histamine from cytokine primed basophils from some donors $(10,28-30)$. It was therefore of interest to determine if eotaxin was also able to stimulate histamine release from basophils. Since murine basophils are not available for study, human basophils were examined. Using basophils from a nonatopic donor and three atopic donors, no histamine release was induced by exposure of fresh cells or cytokine (IL-3 or IL-5)-stimulated cells to murine or human eotaxin. In contrast, MCP-1 and MCP-3 induced histamine release from cytokine primed cells (data not shown). For example, IL-3 primed cells released $36 \pm 25$ and $3.6 \pm 2.6 \%$ histamine (mean $\pm 50, \mathrm{n}=4$ ) when stimulated with 500 $\mathrm{ng} / \mathrm{ml}$ of human MCP-1 or human eotoxin, respectively.

\section{DISCUSSION}

Recombinant murine eotaxin has been expressed in bacteria and the properties of the purified protein have been examined. Biological activity of the protein was dependent upon removal of the amino-terminal tag and appears to require the presence of a protein that starts with the native mature sequence (HPGS ...). This is similar to what has been seen with recombinant MCP-1, where the addition of an amino-terminal tag or modifying the amino terminal amino acid (glutamine) results in loss of macrophage chemotactic activity $(31,32)$. Although eotaxin from guinea pigs, mice, and humans have a different first amino acid than MCP-1, -2 , and -3 , the important role of the amino terminus appears to be conserved. Biological activity was also shown to be dependent upon the presence of the first 25 amino acids since an eotaxin derivative lacking the first 25 amino acids had no biological activity. The requirement for intact amino-terminal amino acids has important implications for the design of therapeutic eotaxin analogs.

Recombinant eotaxin protein was found to be present as a mixture of higher molecular species most likely representing protein aggregation. It is interesting that eotaxin lacking the first 25 amino acids (Lane 3 in Fig. 1B) also appeared to aggregate, indicating that the first 25 amino acids do not appear to be necessary for protein aggregation. Aggregation is known to occur with other chemokines. In the case of IL-8, although aggregation occurs, the monomer maintains full biological activity (40). It remains to be determined if eotaxin aggregation serves an important function. Nevertheless, using a protein preparation that contained a mixture of aggregates, eotaxin delivered direct and potent chemotactic and calcium flux responses to murine eosinophils, with a peak effect noted at $\sim 100 \mathrm{ng} / \mathrm{ml}$. 
It was important to determine if the selectivity of eotaxin for guinea pig eosinophils (which has only been addressed in vivo) is applicable in other species. Since guinea pigs contain larger numbers of baseline eosinophils than mice or humans and is a species in which it is relatively easy to induce allergic models (41), it was possible that eotaxin's unique properties may not be extendible to other species. We first addressed this selectivity in vitro and found that murine eotaxin stimulated eosinophils and not neutrophils, macrophages, or basophils. This selectivity is similar to that we observed for human eotaxin on cells from nonatopic or mildly atopic donors (4). In a recent report, human eotaxin was shown to selectively induce eosinophil transmigration through endothelial cells and to have only a small effect on monocytes at $1000 \mathrm{ng} / \mathrm{ml}$ (5). Thus, in contrast to all other C-C chemokines, eotaxin has no significant effect on macrophages in vitro.

We next examined the selectivity of eotaxin in vivo and demonstrated that the application of eotaxin to wild-type mice produced only a small and variable eosinophil recruitment. In contrast, in the presence of $\mathrm{IL}-5$, eotaxin induced a marked eosinophil selective recruitment. Although the dose of eotaxin that was required to induce this effect was high, only a small amount of the eotaxin delivered to the nose is likely to be deposited in the lung, the organ that was analyzed. During the preparation of this manuscript, purified human eotaxin was shown to selectively induce eosinophils when injected into the skin of a single rhesus monkey (5). In another report, the direct administration of mouse eotaxin (via a crude supernatant from eotaxin transfected myeloma cells) to the lung of wild-type mice was able to induce a selective eosinophil recruitment (20). Although the effect in the lungs was considerably smaller ( $\sim 10$-fold) than the effect we observed in the lungs of IL- 5 transgenic mice ( $\sim 500$-fold increase), it is likely that other products present in the crude supernatant were able to enhance the effect of eotaxin. Alternatively, the differences in these studies may result from variations between the animals (e.g., their endogenous levels of IL-5). The strength of our study is that purified eotaxin alone was delivered and found to recruit huge numbers of eosinophils into the mouse lung only in the presence of IL-5. The cooperativity with IL-5 is similar to that reported in the guinea pig (24). The effect of IL-5 is likely to be the result of increasing both the eosinophil pool (24) and the responsiveness of eosinophils to eotaxin. If this model is correct, then in the absence of other eosinophil active cytokines (e.g., IL-5), eotaxin may only promote low levels of eosinophil recruitment as required for baseline homing. Following an inflammatory trigger, such as during the late-phase response after allergen exposure, IL- 5 is generated along with increased eotaxin. The IL-5 promotes eotaxin responsiveness and prolongs eosinophil survival (which eotaxin does not promote), resulting in the significant tissue eosinophilia seen in various eosinophilic inflammatory states.

Multiple chemokines often bind to the same receptor. It has been unclear if eotaxin binds to eosinophils via a receptor that is shared with other chemokines. Eosinophils preferentially express two $\mathrm{C}-\mathrm{C}$ chemokine receptors, CC CKR-1 and CC CKR-3 (Refs. 14, 15, and 17, and J.-L. Gao et al., submitted). Eosinophils and macrophages are thought to use the same receptor to respond to MIP- $1 \alpha$, RANTES, and possibly MCP-3, presumably CC CKR-1 $(9,11,42)$. Guinea pig eotaxin and human RANTES appear to compete for the same receptor on human eosinophils (2). However, human RANTES is not a functional agonist for guinea pig eosinophils and it is therefore difficult to draw any firm conclusions from these studies. One way to begin to determine if eotaxin shares a binding site with these other chemokines is to determine if eotaxin and other chemokines cross-desensitize eosinophils to subsequent cellular signaling. Murine MIP-l $\alpha$ (since this was the only murine eosinophil active chemokine available) was studied with murine eotaxin. Eotaxin consistently delivered a larger calcium flux than MIP- $1 \alpha$ in eosinophils, perhaps indicating that eotaxin is more physiologically active on eosinophils. Neither chemokine was able to cross-desensitize to each other indicating that they used distinct receptor pathways. It was recently reported that human RANTES and MCP-3 (which are not available for study in mice) but not MIP- $1 \alpha$ were able to desensitize human eosinophils to human eotaxin (5). Interestingly, these investigators found that treatment of human eosinophils with human eotaxin caused complete desensitization to subsequent signaling with MIP- $1 \alpha$, RANTES, and MCP-3. In our study in mice, we did not find that eotaxin desensitized to MIP- $1 \alpha$. This may be related to a difference between species or modification of the receptor signaling pathway by IL-5 in vivo (since the mouse eosinophils were isolated from IL- 5 transgenic mice). Alternatively, the difference may be due to the fact that the eosinophils from the 
study by Ponath et al. were examined only from patients with high levels of eosinophilia. Such eosinophils often have different characteristics from eosinophils from patients without eosinophilia (37). Nevertheless, the lack of desensitization of eotaxin to subsequent MIP- $1 \alpha$ signaling, indicates that eosinophils utilize at least two distinct chemokine receptor pathways. The eotaxin receptor is likely to be conserved between mice and human since we have recently been able to demonstrate that eotaxin (and not MIP- $1 \alpha$ ) induces a calcium flux in cells transfected with murine CC CKR-3 (J.-L. Gao et al., submitted). It is interesting that eosinophils appear to express much higher levels of CC CKR-3 than CC CKR-1 and the expression of CC CKR-3 is very restricted to eosinophils. This may explain the failure of eotaxin to liberate histamine release from basophils and the remarkable selectivity of eotaxin. The exact binding domains on eotaxin for eosinophil receptor signaling are not known; however, amino acids within the first 25 residues are critical since the eotaxin derivative lacking these amino acids has no activity.

The results of this study demonstrate that eotaxin is highly selective for eosinophils in vivo and in vitro, has markedly enhanced chemoattractive activity for eosinophils in the presence of IL-5 in vivo, and utilizes a receptor pathway that is not shared with MIP- $1 \alpha$. This suggests that the development of tissue eosinophilia in vivo involves a two-step mechanism elicited by interleukin 5 (or possibly other eosinophil growth factors) and eotaxin. A further understanding of eotaxin and its interaction with IL-5 may lead to new therapeutic modalities for treating allergic and malignant diseases.

\section{ACKNOWLEDGMENTS}

We thank Dr. John Rush and Ivar Jensen for amino-terminal sequence analysis and Joy Rothenberg for helpful discussions. This work was supported in part by a Cancer Research Institute/Benjamin Jacobson Family Investigator Award (ADL).

\section{REFERENCES}

1. Sanderson CJ. (1992) Interleukin-5, eosinophils, and disease. Blood 79: 3101-3109.

2. Jose PJ, Griffiths-Johnson DA, Collins PD, et al. (1994) Eotaxin-A potent eosinophil che- moattractant cytokine detected in a guinea pig model of allergic airways inflammation. J. Exp. Med. 179: 881-887.

3. Rothenberg ME, Luster AD, Leder P. (1995) Murine eotaxin-An eosinophil chemoattractant inducible in endothelial cells and in interleukin 4-induced tumor suppression. Proc. Natl. Acad. Sci. U.S.A. 92: 8960-8964.

4. Garcia-Zepeda EA, Rothenberg ME, Ownbey RT, Celestin, J. Leder P, Luster AD. (1996) Human eotaxin is a specific chemoattractant for eosinophil cells and provides a new mechanism to explain tissue eosinophilia. Nature Med. 2: 449-456.

5. Ponath PD, Qin S, Ringler DJ, et al. (1996) Cloning of the human eosinophil chemoattractant, eotaxin: Expression, receptor binding, and functional properties suggest a mechanism for the selective recruitment of eosinophils. J. Clin. Invest. 97: 604-612.

6. Baggiolini M, Dewald B, Moser B. (1994) Interleukin-8 and related chemotactic cytokines-CXC and CC chemokines. $A d v$. Immunol. 55: 97-179.

7. Kelner GS, Kennedy J, Bacon KB, et al. (1994) Lymphotactin: A cytokine that represents a new class of chemokine. Science 266: 1395-1399.

8. Murphy PM. (1994) The molecular biology of leukoctye chemoattractant receptors. Annu. Rev. Immunol. 12: 593-633.

9. Rot A, Krieger M, Brunner T, Bischoff SC, Schall TJ, Dahinden CA. (1992) RANTES and macrophage inflammatory protein 1 alpha induce the migration and activation of normal human eosinophil granulocytes. $J$. Exp. Med. 176: 1489-1495.

10. Dahinden CA, Geiser T, Brunner T, et al. (1994) Monocyte chemotactic protein 3 is a most effective basophil- and eosinophil-activating chemokine. J. Exp. Med. 179: 751756.

11. Weber $M$, Uguccioni $M$, Ochensberger $B$, Baggiolini M, Clark-Lewis I, Dahinden CA. (1995) Monocyte chemotactic protein MCP-2 activates human basophil and eosinophil leukocytes similar to MCP-3. J. Immunol. 154: 4166-4172.

12. Neote K, DiGregorio D, Mak JY, Horuk R, Schall TJ. (1993) Molecular cloning, functional expression, and signaling characteristics of a C-C chemokine receptor. Cell 72: 415-425.

13. Charo IF, Myers SJ, Herman A, Franci C, Connolly AJ, Coughlin SR. (1994) Molecu- 
lar cloning and functional expression of two monocyte chemoattractant protein 1 receptors reveals alternative splicing of the carboxyl-terminal tails. Proc. Natl. Acad. Sci. U.S.A. 91: 2752-2756.

14. Combadiere C, Ahuja SK, Murphy PM. (1995) Cloning and functional expression of a human eosinophil CC chemokine receptor. J. Biol. Chem. 270: 16491-16494.

15. Post TW, Bozic CR, Rothenberg ME, Luster AD, Gerard N, Gerard C. (1995) Molecular characterization of two murine eosinophil beta chemokine receptors. J. Immunol. 155: 5299-5305.

16. Power CA, Meyer A, Nemeth K, et al. (1995) Molecular cloning and functional expression of a novel CC chemokine receptor cDNA from a human basophilic cell line. J. Biol. Chem. 270: 19495-19500.

17. Combadiere C, Ahuja SK, Murphy PM. (1995) Cloning, chromosomal localization, and RNA expression of a human beta chemokine receptor-like gene. DNA Cell Biol. 14: 673-680.

18. Jose PJ, Adcock IM, Griffiths-Johnson DA, et al. (1994) Eotaxin: Cloning of an eosinophil chemoattractant cytokine and increased mRNA expression in allergen-challenged guinea-pig lungs. Biochem. Biophys. Res. Commun. 205: 788-794.

19. Rothenberg ME, Luster AD, Lilly CM, Drazen JM, Leder P. (1995) Constitutive and allergen-induced expression of eotaxin mRNA in the guinea pig lung. J. Exp. Med. 181: $1211-1216$.

20. Gonzalo J-A, Jia G-Q, Aquirre V, et al. (1996) Mouse eotaxin expression parallels eosinophil accumulation during lung allergic inflammation but is not restricted to a Th2type response. Immunity 4: 1-14.

21. Foster PS, Hogan SP, Ramsay AJ, Matthaei KI, Young IG. (1996) Interleukin 5 deficiency abolishes eosinophilia, airways hyperreactivity, and lung damage in a mouse asthma model. J. Exp. Med. 183: 195-201.

22. Kopf $M$, Brombacher F, Hodgkin PD, et al. (1996) IL-5-deficient mice have a developmental defect in $\mathrm{CD}^{+}$B-1 Cells and lack eosinophilia but have normal antibody and cytotoxic $\mathrm{T}$ cell responses. Immunity 4: 1524.

23. Dent LA, Strath M, Mellor AL, Sanderson CJ. (1990) Eosinophilia in transgenic mice expressing interleukin 5. J. Exp. Med. 172: $1425-1431$.
24. Collins PD, Marleau S, Griffithsjohnson DA, Jose PJ, Williams TJ. (1995) Cooperation between interleukin-5 and the chemokine eotaxin to induce eosinophil accumulation in vivo. J. Exp. Med. 182: 1169-1174.

25. Luo Y, Laning J, Devi S, Mak J, Schall TJ, Dorf ME. (1994) Biologic activities of the murine beta-chemokine TCA3. J. Immunol. 153: 4616-4624.

26. Force T, Hyman G, Hajjar R, Sellmayer A, Bonventre JV. (1991) Noncyclooxygenase metabolites of arachidonic acid amplify the vasopressin-induced $\mathrm{Ca}^{2+}$ signal in glomerular mesangial cells by releasing $\mathrm{Ca}^{2+}$ from intracellular stores. J. Biol. Chem. 266: 42954302.

27. Rothenberg ME, Petersen J, Stevens RL, et al. (1989) IL-5-dependent conversion of normodense human eosinophils to the hypodense phenotype uses 3T3 fibroblasts for enhanced viability, accelerated hypodensity, and sustained antibody-dependent cytotoxicity. J. Immunol. 143: 231 1-2316.

28. Alam R, Forsythe PA, Stafford S, Lett-Brown MA, Grant JA. (1992) Macrophage inflammatory protein-1 alpha activates basophils and mast cells. J. Exp. Med. 176: 781-786.

29. Alam R, Lett BM, Forsythe PA, et al. (1992) Monocyte chemotactic and activating factor is a potent histamine-releasing factor for basophils. J. Clin. Invest. 89: 723-728.

30. Bischoff SC, Krieger M, Brunner T, Dahinden CA. (1992) Monocyte chemotactic protein 1 is a potent activator of human basophils. J. Exp. Med. 175: 1271-1275.

31. Gong JH, Clark-Lewis I. (1995) Antagonists of monocyte chemoattractant protein 1 identified by modification of functionally critical $\mathrm{NH}_{2}$-terminal residues. J. Exp. Med. 181: 631-640.

32. Zhang YJ, Rutledge BJ, Rollins BJ. (1994) Structure/activity analysis of human monocyte chemoattractant protein-1 (MCP-1) by mutagenesis. Identification of a mutated protein that inhibits MCP-1-mediated monocyte chemotaxis. J. Biol. Chem. 269: 15918-15924.

33. Luster AD, Greenberg SM, Leder P. (1995) The IP-10 chemokine binds to a cell surface heparan sulfate site shared with platelet factor 4 and inhibits endothelial cell proliferation. J. Exp. Med. 182: 219-231.

34. Schild HO. (1973) Receptor classification with special reference to $\beta$-adrenergic recep- 
tors. In: Rang HP (ed). Drug Receptors. University Park Press, Baltimore, pp. 29-36.

35. Kurup VP, Mauze S, Choi H, Seymour BW, Coffman RL. (1992) A murine model of allergic bronchopulmonary aspergillosis with elevated eosinophils and IgE. J. Immunol. 148: $3783-3788$.

36. Van Oosterhout AJ, Fattah D, Van Ark I, Hofman G, Buckley TL, Nijkamp FP. (1995) Eosinophil infiltration precedes development of airway hyperreactivity and mucosal exudation after intranasal administration of interleukin-5 to mice. J. Allergy Clin. Immunol. 96: 104-112.

37. Sehmi R, Wardlaw AJ, Cromwell O, Kurihara K, Waltmann P, Kay AB. (1992) Interleukin- 5 selectively enhances the chemotactic response of eosinophils obtained from normal but not eosinophilic subjects. Blood 79: 2952-2959.

Contributed by P. Leder on March 3, 1996.
38. Ebisawa M, Bochner BS, Georas SN, Schleimer RP. (1992) Eosinophil transendothelial migration induced by cytokines. I. Role of endothelial and eosinophil adhesion molecules in IL-1 beta-induced transendothelial migration. J. Immunol. 149: 4021-4028.

39. Yamaguchi $Y$, Suda T, Ohta S, Tominaga $K$, Miura Y, Kasahara T. (1991) Analysis of the survival of mature human eosinophils: Interleukin-5 prevents apoptosis in mature human eosinophils. Blood 78: 2542-2547.

40. Rajarathnam K, Sykes BD, Kay CM, et al. (1994) Neutrophil activation by monomeric interleukin-8. Science 264: 90-92.

41. Kallos P, Kallos L. (1984) Experimental asthma in guinea pigs revisited. Int Arch Allergy Appl Immunol 73: 77-85.

42. Baggiolini M, Dahinden CA. (1994) CC chemokines in allergic inflammation. Immunol. Today 15: 127-133. 